\title{
2. Six Oceania microstates: The genesis of media accountability
}

\section{ABSTRACT}

Media accountability systems $\left(\mathrm{M}^{*} \mathrm{~A} * \mathrm{~S}\right)$ have been slow to take root in Oceania. Apart from Papua New Guinea, Fiji is the trend-setter in the region. Following the establishment of the Fiji Media Council in the mid 1990s, several other South Pacific island countries were keen to the follow the lead. Tonga now has a similar body with a code of ethics and which includes public members empowered to receive and adjudicate on complaints against the media. In Samoa, a study has been carried out in order to establish a media council-type body. The Solomons Islands Media Council (SIMC) is an industry organisation that does not yet have a complaints procedure. It is considering including this mechanism in line with the Papua New Guinea Media Council with which it shares a website and has a cooperative agreement. This article examines the debate in six South Pacific island countries that have adopted, or are in the process of adopting, self-regulatory $\mathrm{M}^{*} \mathrm{~A}{ }^{*} \mathrm{~S}$ mechanisms following government pressure. They are the Cook Islands, Fiji, Kiribati, Samoa, Solomon Islands, Tonga and Vanuatu. The article also argues that there are other $\mathrm{M}^{*} \mathrm{~A} * \mathrm{~S}$ that regional media can adopt besides media councils and this action would make it harder for governments to intervene and introduce regulation.

SHAILENDRA SINGH

University of the South Pacific

\section{Introduction}

TN THE early 1990s, the Fiji government, claiming that the press was becoming a menace to society and calling for a more accountable media,

commissioned the Thomson Foundation of Britain to carry out a study on 'Future Media Legislation and Regulation for the Republic of the Fiji Islands'. In reality, the study followed a sustained period of tension between 
the government and the media during which the media broke new ground, reporting a sex scandal involving the then Prime Minister Sitiveni Rabukaand a woman journalist in 1994, followed by the National Bank of Fiji disaster which eventually cost taxpayers F $\$ 400$ million. Clearly, the media was becoming bolder and more intrusive. The Government was unaccustomed to, and uncomfortable with, this type of brashness. However, whatever faith it may have had in the Thomson Report recommendations offering some kind of regulatory role were misplaced. While the report led to the establishment of the self-regulating Fiji Media Council in 1998 and opened an avenue for the hearing of public complaints against the media, it said the most appropriate system for Fiji media accountability ought to be applied by an independent, non-governmental body (Morgan \& Thomas, 1996, p. 17).

Fiji, for better or worse, is the trend-setter in the region apart from Papua New Guinea. Following the establishment of the Fiji Media Council, several other South Pacific island countries were keen to the follow. Tonga now has a similar body with a code of ethics and public members empowered to receive and adjudicate on complaints. In Samoa, a study has been carried out under the auspices of the Thomson Foundation recommending the setting up of a media council-type body.

The Cook Islands media is considering reviving its media council following government threats to pass media legislation. The Solomons Islands Media Council (SIMC) is an industry organisation that does not yet have a complaints procedure. But it plans to include this mechanism in line with the Papua New Guinea Media Council, with which it shares a website and has a cooperative agreement.

Another recent trend in Fiji is cause for concern. In 2003, the Laisenia Qarase government introduced the controversial Media Council of Fiji Bill calling for the dissolution of the self-regulating Fiji Media Council to be replaced with a statutory body stacked with government appointees, including the chairman. While the bill was shelved following a public furor, it raised questions of whether the establishment of the Fiji Media Council Ltd had been the thin edge of the wedge to facilitate the establishment of the statutory regulatory body. It has also raised the spectre of other governments in the region following Fiji's example by first calling for an independent media council, then trying to legislate it. In Vanuatu, because of such a fear, not all the media is keen about the establishment of a media council while in the Cook Islands, the government's strong and persistent calls for a media coun- 
cil has raised the media's suspicions. This article examines six South Pacific Island countries that have adopted, or are in the process of adopting, media council-type self-regulatory mechanisms following government pressure. The media in the Cook Islands, Fiji, Samoa, Solomon Islands, Tonga and Vanuatu vary in size and development. The common characteristic about them is that they have all been vocal and fearless critics of government abuse in their respective countries. For this reason, they have faced intense and unrelenting pressure from successive governments. While the effectiveness of media councils may be questioned by some, for these island nations at this stage of the development of their media, such bodies clearly represent the best means of keeping the media accountable and the government at bay.

\section{Background}

Media self-regulation is scoffed at and ridiculed by some analysts. The critics include not only governments and private citizens who may have been 'burnt' by the media, but also practitioners. Their argument, basically, is that allowing the media to self-regulate and trusting it to do a good job is - to use a cliché, but an apt one - as foolish and as misguided as handing over the control of the blood bank to Count Dracula.

Some critics are especially disdainful of media councils, condemning their press complaints commissions and their codes of ethics as of little value. They include Sir David Calcutt, who dismissed Britain's Press Complaints Commission as not the truly independent body it should be, and thus not an effective regulator of the press:

As constituted, it is, in essence, a body set up by the industry, financed by the industry, dominated by the industry and operating a code of practice devised by the industry, and which is over-favourable to the industry. (Cited by Elsaka, 1993, p. 9)

Equally contemptuous is former Times correspondent Bob Norris, who says media council-style formal codes of ethics 'all have one thing in common: they are not worth the paper they are written on' (cited by Keeble, 2005, p. 54). Nadia Elsaka (2001) questions the functionality of the media council code of ethics, noting that both the establishment of self-regulatory structures and their later reform in Britain were driven by parliamentary pressure. She argues that since self-regulatory codes were 'externally-driven' reactions to 
'perceived' threats to media freedom rather than internally-inspired and proactive self-regulatory reform underpinning the concept of voluntary restrain, they are by nature self-serving and thus ineffective.

...the experience of the British press indicates that self regularity codes of ethics have not been adopted to promote the privacy rights of news subjects, but primarily to deflect threats of statutory regulation (Elsaka, 2001, p. 160).

David Robie (2004) highlighted that when it came to the crunch, the Fiji media often failed to adhere to the Fiji Media Council's code of ethics. He pointed to the sensationalised coverage of the double-murder of former Fiji Red Cross director John Scott and his partner Greg Scrivener in July 2002 (Robie, 2003, pp. 106-107). He also found that while there had been heated debate for four years over professional and ethical issues over the coverage of George Speight's attempted coup in May 2000, the council had adjudicated only four complaints in three years since then, with just one related to the political upheaval, which was dismissed (2004, p. 54).

Clearly, media self-regulation is under both enemy and friendly fire. In the cacophony, it is sometimes difficult to determine which is more critical - the bullets coming from the government side or fellow media practitioners. This is not to say that analysis and criticism of media accountability systems by media commentators are unwelcome. The scrutiny has in fact been largely healthy in that it has resulted in the continuous self-examination, evaluation and overhauling of systems. The media has been, by and large, responsive to public sentiment, only drawing the line when it felt that its proper functioning as a watchdog would be compromised. The media in Oceania is rightly suspicious of the motivation behind government criticisms, particularly when it has exposed many financial scams implicating the state.

Just as the British and New Zealand media formed self-regulatory bodies following pressure from Parliament or perceived threats to media freedom, so did the six countries which are the subject of this paper, and whose media, and press and media councils, are based on a British model. But whether such actions are purely motivated by self-preservation and thus ineffective in terms of making the media accountable, as Elsaka appears to be suggesting, is open for debate. The Fiji News Council, for instance, was essentially an industry body before it become the Fiji Media Council by including a complaints- 
hearing mechanism and adopting a code of ethics. Similarly, press councils in other Pacific countries are moving towards becoming fully-fledged media councils with mechanisms for the public airing of complaints. From being an exclusive editors' club, the press councils, by inducting public members into their realm, adding mechanisms to hear and adjudicate complaints and adopting a media code of ethics, are being responsive not just to demands from governments but also to calls from the public. This process has been beneficial not only because it opens up the media to greater public scrutiny and higher standards, but also because it holds the media accountable.

Because the public demands much from them, the media councils are now held responsible and accountable for media standards. Stung by criticisms of being a 'toothless tiger' and 'publishers' poodle', and blamed when journalists belonging to its member organisation breached the code of ethics, the Fiji Media Council has been forced to become more proactive. While it has heard more than 170 cases since its inception (Pratt, 2005), unlike when it was first formed, the council is doing more than just adjudicating; it has started training workshops for journalists and organises an 'editors forum' seminar series at which important national issues are opened up for public debate. In October this year, it teams up with the Institute of Governance at the University of the South Pacific, the Fiji Electoral Commission and the Fiji Elections Office to organise a Media and Elections workshop to prepare journalists for Fiji's general elections next year.

This is an example of the continuous evolution media councils have to undergo to keep abreast of the changing situation and in order to remain credible and relevant.

\section{The Pacific Island situation}

\section{Cook Islands}

In 2004, the Cook Islands government gave the media an ultimatum-form a self-regulating media council or have government legislate the media. Atiu MP and adviser to the prime minister, Norman George, said they would 'try the gentlemanly way first' but would impose legislation if the government did not see the results it wanted.

We do not want to interfere with the freedom of the media or abolish anyone's media interest. Government is only concerned that this country should be saved from gutter media standards. We are saying, 'Come

46 PACIFIC JOURNALISM REVIEW 11 (2) 2005 
on guys, the situation is getting completely out of hand. You have been given unfettered free reign but you have completely abused it. Self regulation by the media has failed and you have to do something about it' (Media offenders to scream first, says George, 2004).

Modeled on the Australian and New Zealand style of press self-regulation, the Cook Islands Media Council (CIMC) existed from 1995-1999. There was a split when secretary Arthur Taripo and media industry representative Trevor Pitt left. The pair later became an integral part of the Pitt Media group, and its industry body, the Cook Islands Media Group (CMG). Veteran Cook Islands journalist Jason Brown contends that the CIMC was the victim of an industry split rather than government interference as claimed by the CMG. He believes that in the absence of a regulatory body, the performance of the media has been very poor (J. Brown, personal communication, August 2005). The Pitt Media Group, which is the dominant media in the Cook Islands with interests in print and broadcast, had been going head-to-head with the government for some time. The group owns two papers, the Cook Islands Herald and the Cook Islands Independent, and operates the island's main radio and television station. The other privately-owned daily newspaper is the Cook Island News. The government view was that the Pitt Media Group, because of its various cross-media holdings, had become too powerful and was abusing this power for its own political end. The government also announced plans to form an interim broadcasting board to make media companies meet the provisions of the Broadcasting Act (Cook Islands PM announces creation of media council, 2004). The CIMA president, Florence Syme-Buchanan, expressed concern about the government's view that 'broadcasting services ought to take government policies into account' (Cautious welcome for media council plan, 2004).

Syme-Buchanan added that the association would only support the development of a press council if it was going to be an independent one. To avoid any attempts to control the media, the association urged the government to introduce a Freedom of Information and Media Act to accompany any monitoring policies. In an editorial, the Cook Islands News criticised the proposed media council as a structure devised by the Government to stop newspapers from investigating and criticising it:

It has been politicians that have demanded regulatory control of the 
MEDIA ETHICS AND ACCOUNTABILITY

media. We know that when a Media Council was established back in the mid-1990s, it was politicians that dominated the submissions in lodging complaints. (Politicians 'want media on a leash', 2004)

\section{Fiji}

Fiji has the largest and most vibrant media in the region, with three English daily newspapers, two weekly vernacular newspapers in Hindi and Fijian, a free-to-air and a pay television station, and several 24-hour radio stations broadcasting in English, Fijian and Hindustani. Most of the 1990s were marked by the growth of the media and a particularly difficult period in governmentmedia relations. The Fiji News Council - the precursor to the current Fiji Media Council-was formed in 1994 during a particularly difficult period in government-media relations.

April 1994 in fact was a groundbreaking year for journalism in Fiji when the Suva-based The Review business magazine reported the country's first political sex scandal - a tryst between then Prime Minister Sitiveni Rabuka and a local woman journalist (Confessions of a prime minister, 1994). The then Information Minister, Josefa Dimuri, threatened to bring in tighter controls and to deregister The Review. But the government, which had come to power on a much-derided racially-based constitution, stopped short of making good on its threat as it apparently did not want to cause an international furore at a time when it was trying to gain international legitimacy. In November 1995, the media blew the lid on the massive National Bank of Fiji scam, which eventually resulted in losses to the nation of more than $\$ 400$ million as a result of dubious loans.

The Review and The Fiji Times began publishing a full list of debtors, including influential people with close connections to government. The coverage of the sex and financial scandals showed that the media was willing to cross uncharted waters in terms of challenging government performance and conduct. It was in this climate that the Rabuka government commissioned the Thomson Foundation to examine media legislation and propose recommendations for a future legal and regulatory structure.

Kenneth Morgan and John Thomas, consultants from the foundation, were in Fiji between 15-28 September 1996. Based on their recommendations, the Fiji News Council was renamed the Fiji Media Council in 1998 and underwent some fundamental changes, including the inclusion of public members, the formation of an independent complaints committee and the adoption of a

48 PACIFIC JOURNALISM REVIEW 11 (2) 2005 
code of ethics. The committee hears complaints concerning any media organisation in Fiji, whether a member of the Media Council or not. Complainants who engage the council have to sign a document waiving any legal rights before proceeding further. The organisation against which a complaint is made is expected to publish the adjudication regardless of whether it is upheld or not. If it does not do so within one week, copies of the adjudication may be released to other media organisations for publication (Complaint procedure, 2003).

The Laisenia Qarase government was clearly not satisfied with the Fiji Media Council and in 2003 proposed the draconian Media Council of Fiji Bill which, apart from calling for a council stacked with government appointees, proposed that offenders be fined up to F\$2000 for breaches. University of the South Pacific journalism lecturer Shailendra Singh (2003) disputed the Government's claims that the proposed Bill was based on the Thomson Foundation recommendations, noting that the consultants said:

...the most appropriate system for Fiji is that the regulation be applied

by an independent, non-government body. (Singh, 2003, p. 12)

The Qarase government's proposed Media Bill was shelved last year after much public opposition although it is not inconceivable that should this government win the 2006 elections, the Bill will be tabled in Parliament.

\section{Samoa}

In Samoa, the media has experienced rapid growth in recent years and with this growth there have been calls for more accountability. Today, the population of 171,000 is served by seven radio stations, including the state-owned public broadcaster, three fully commercial stations owned by a single company and two owned (separately) and operated by the Pentecostal churches. In television, there is the state-owned channel, two cable TV stations, one with three channels, and the other with four channels, both privately owned, and a religious station carrying Pentecostal American based religious programmes.

The country has several privately owned newspapers - one daily except for Monday, a thrice weekly and a weekly. In addition, there are three Samoan language newspapers published out of Auckland, New Zealand, and distributed in Samoa while the government also publishes its own weekly 
newspaper. Samoan Prime Minister, Tuilaepa Sailele, has been at the forefront of calls for a media council. The Samoan media has taken heed and is moving towards self-regulation through a press or media council under the auspices of the Journalists Association of Western Samoa (JAWS) that looks after the interest of journalists.

According to the editor and owner of the LeSamoa newspaper, Patu Faumuina Apulu Lance Polu, all the interested parties, including media organisations, are considering the report of Thomson Foundation consultant Ian Beales. The study was sponsored by the Commonwealth Media Development Fund (L. Polu, personal communication, 2005).

The proposed council should have a wide representation, including public as well as media representatives, adopt a code of ethics and establish a committee to oversee compliance and to look into complaints against the media. It was not too long ago that Samoan journalists were regularly threatened, summoned to Parliament, or indicted with criminal and civil libel cases, and injunction actions, to prevent them publishing information. Polu said things had since improved. He is hopeful that the establishment of the media council would lead to further progress. Samoa still has a criminal libel law and a Printers and Publishers Act which Polu says should be abolished once a media council is in place.

\section{Solomon Islands}

The Media Association of the Solomon Islands (MASI), formed in 1978, was revamped following a partnership agreement with Papua New Guinea Media Council in 2003 (Media Council of PNG). MASI presently operates more as a professional association, but plans are underway to follow a similar line as the Media Council of PNG. MASI is recognised by the government, NGOs, and the civil society in the Solomon Islands as a professional body that represents the media in the country. It is also recognised by regional and international media institutions and watchdogs.

While MASI does not act as an adjudicator, it clearly sees its role as defender of the media and journalists, and has been very vocal in this capacity. It has been particularly active when public officials attempt to pressure the media, and try to censor coverage.

Following its partnership agreement with PNG's Media Council, MASI is moving towards becoming a self-regulatory body for the media. The two organisations have been working together as partners since 2003 and share a

50 PACIFIC JOURNALISM REVIEW 11 (2) 2005 
website. MASI membership includes all the major media organisations in the Solomon Islands, but currently it also accepts individual and associate membership. MASI is involved in providing media training for local journalists to 'improve reporting standards and improve professionalism within the industry'. The association also supports anti-corruption campaigns within the South Pacific.

The constitution of MASI calls for it to actively support the professional development of the media in the Solomon Islands. It has developed a Code of Ethics for the media (Solomon Islands: policies, 2005).

\section{Tonga}

In Tonga, the Government has a heavy presence in the print and broadcast media. It owns one of the three newspapers and runs the national television and radio station. The state-owned media tends to toe the government line. Privately-owned broadcast media mostly air foreign programmes, music and news. It is the print media that carries opposition views with which the Tongan government has mostly clashed. In 2003, the government went to extraordinary lengths to gag the media by amending clause 7 of the Tongan Constitution guaranteeing free speech and press freedom, and introducing accompanying legislation in the Newspaper Act and the Media Operators Act.

The new laws required vendors to obtain licences to distribute their publications in the country. It was clearly aimed at the Taimi o' Tonga newspaper owned by Auckland-based publisher and long-time government critic, Kalafi Moala. The paper had, over the years, run a series of highly embarrassing reports on the Tongan monarchy and government. A government move to gag the media galvanised the Tongan media into action and led to the establishment of the Tonga Media Council Inc. in August 2003. According to the council's website, with the introduction of the new media laws, journalists in Tonga realised that:

There was a need for a strong organisation to safeguard press freedom, raise the standard of journalism, and create a forum for dialogue with the government on media-related legislation and other matters. (About the Media Council Inc., 2005)

Chaired by veteran publisher Pesi Fonua, the council is administered by a board of directors selected by each of the six news organisation. The mem- 
bership comprises six Tongan news organisations. The council has a training committee and a complaints committee that is run on a voluntary basis. It lists defending media freedom, training news professionals and adjudicating complaints as its major responsibilities. Strengthening the council's structure and engaging with government on media-related issues are the other priorities.

The complaints committee has yet to hear a case. Fonua says they receive complaints over the phone but when people are asked to put their complaints in writing, they usually do not pursue it further (P. Fonua, personal communication, 2005). As a result, the committee has decided that it will take on the responsibility of putting in writing the complaints of callers and get them to sign the document.

\section{Vanuatu}

The media scene in Vanuatu is also very vibrant. Apart from the state-owned Vanuatu Weekly newspaper, there are four privately owned weekly or bi-weekly publications. Radio Vanuatu and Television Blong Vanuatu are state-owned ventures broadcasting under the Vanuatu Broadcasting and Television Corporation.

Sections of the Vanuatu media feel that the level of media development should be consistent with the development of media accountability and that the letters to the editor section is not sufficient for redress. In 2003, the Association de Medias Francophones called for the establishment of such a body to receive complaints and resolve disputes between the media and the public.

But the Media Association of Vanuatu president, Kiery Manassah, believes there is no pressing need for a such a body and is suspicious of the motives of some of those calling for such a system:

Let the leaders and politicians, who are often the ones trying to shoot the messenger, be accountable first. After all, they are the managers of public resources, not the media. (Manassah, 2005)

Manassah's wariness is borne out of witnessing successive corrupt governments over many years attempting to gag the media after it revealed mismanagement on a massive scale. This includes the attempted illegal deportation of Vanuatu Post publisher Marc Neil-Jones in January 2001 for writing a series of articles on government corruption. Neil-Jones was served a deportation order at 5am and asked to leave without his medication or change of 
clothes. In a bizarre move, the then Prime Minister, Barak Sope, tried to change the law to legalise his action after it was thrown out by the country's then acting chief justice.

\section{Supplementary $\mathbf{M} * \mathbf{A} * \mathbf{S}$ systems}

While the focus in the region is on press or media councils, it is important to note that other $M^{*} A^{*} S$ that are in place to supplement these councils have been overlooked (See Table 1). The www.presscouncils.org website lists more than 80 systems that are used to encourage the news media and journalists to respect ethical rules set by the profession. It says that more systems can and will be invented, underscoring the fact that the processes are continuously changing, evolving and improving (see Bertrand, 2003). Bertrand has identified and divided these systems into three categories - internal, external and cooperative $\mathrm{M}^{*} \mathrm{~A} * \mathrm{~S}$ (Bertrand, 2003, p. 125). The MAS that are present in Oceania under these categories include:

- Internal - correction boxes, internal memos and in-house codes of ethics.

- External-journalism review, alternative media, critical book/review, media-related NGO or foundation, higher education, and media observatory.

- Cooperative-letters to the editor, local press councils and continuous education.

In terms of external $\mathrm{M}^{*} \mathrm{~A} * \mathrm{~S}$, three universities in the region run journalism programmes - the University of the South Pacific (USP), University of Papua New Guinea (UPNG) and Divine World University (DWU). By 2004, USP had produced 81 degree and diploma holders for the Pacific Media Industry (Robie, 2004, p. 198). The USP programme's Media Law and Ethics course is compulsory for all students, including experienced journalists.

The programme publishes the Ossie Award winning-quarterly newspaper, Wansolwara, which has a Fourth Estate column devoted to media issues and the website, Pacific Journalism Online, which also discusses media ethics and accountability.

NGOs such as the Fiji Media Watch (FMW), the Citizens Constitutional Forum (CCF) and the Fiji Institute of Applied Studies (FIAS) that interact with the media also fall into Bertrand's external $M^{*} \mathrm{~A} * \mathrm{~S}$ category and are quite important in lobbying for higher media standards.

The FMW is a non-government organisation monitoring the local media 
MEDIA ETHICS AND ACCOUNTABILITY

Table 1: $M^{*} A^{*} S$ systems in six Pacific nations

\begin{tabular}{|c|c|c|c|c|c|}
\hline Internal $\mathbf{M}^{*} \mathbf{A}^{*} \mathbf{S}$ & Fiji & Samoa & Solomons & Tonga & Vanuatu \\
\hline Correction box & $\checkmark$ & $\sqrt{ }$ & $\checkmark$ & $\checkmark$ & $\sqrt{ }$ \\
\hline Media reporter & - & - & - & - & - \\
\hline In-house critic & - & - & - & - & - \\
\hline Disciplinary committee & - & - & - & - & - \\
\hline Media page/program & - & - & - & - & - \\
\hline Internal memo & - & - & - & - & - \\
\hline Code of ethics & $\checkmark$ & $\checkmark$ & $\sqrt{ }$ & $\sqrt{ }$ & $\checkmark$ \\
\hline Ethical audit & - & - & - & - & - \\
\hline Ethics coach & - & - & - & - & - \\
\hline Ombudsman & - & - & - & - & - \\
\hline Opinion survey & - & - & - & - & - \\
\hline Company of journalists & - & - & - & - & - \\
\hline External $M^{*} A^{*} S$ & Fiji & Samoa & Solomons & Tonga & Vanuatu \\
\hline Journalism review & $\checkmark$ & $\checkmark$ & $\checkmark$ & $\sqrt{ }$ & $\checkmark$ \\
\hline Alternative media & $\sqrt{ }$ & $\sqrt{ }$ & $\sqrt{ }$ & $\sqrt{ }$ & $\sqrt{ }$ \\
\hline Critical book/report & $\sqrt{ }$ & $\sqrt{ }$ & $\sqrt{ }$ & $\sqrt{ }$ & $\sqrt{ }$ \\
\hline Public statements & - & - & - & - & - \\
\hline $\begin{array}{l}\text { Media-related NGO or } \\
\text { Foundation }\end{array}$ & $\checkmark$ & $\checkmark$ & $\checkmark$ & $\checkmark$ & $\checkmark$ \\
\hline Media observatory & - & - & - & - & - \\
\hline Non-profit research & - & - & - & - & - \\
\hline Higher education & $\sqrt{ }$ & $\sqrt{ }$ & $\checkmark$ & $\sqrt{ }$ & $\sqrt{ }$ \\
\hline Media at school & - & - & - & - & - \\
\hline Consumer group & - & - & - & - & - \\
\hline $\begin{array}{l}\text { Assoc. of militant } \\
\text { citizens }\end{array}$ & - & - & - & - & - \\
\hline Company of users & - & - & - & - & - \\
\hline Public broadcasting & $\sqrt{ }$ & $\sqrt{ }$ & $\sqrt{ }$ & $\sqrt{ }$ & $\sqrt{ }$ \\
\hline Regulatory agency & - & - & - & - & - \\
\hline Cooperative $M^{*} A^{*} S$ & Fiji & Samoa & Solomons & Tonga & Vanuatu \\
\hline Letters to the editor & $\checkmark$ & $\checkmark$ & $\checkmark$ & $\checkmark$ & $\checkmark$ \\
\hline Public access & - & - & - & - & - \\
\hline Paid-for opinion page & $\checkmark$ & $\sqrt{ }$ & $\sqrt{ }$ & $\sqrt{ }$ & $\sqrt{ }$ \\
\hline $\begin{array}{l}\text { Accuracy and fairness } \\
\text { questionnaire }\end{array}$ & - & - & - & - & - \\
\hline Consulting with users & - & - & - & - & - \\
\hline Liaison committee & - & - & - & - & - \\
\hline Local press council & $\sqrt{ }$ & - & $\sqrt{ }$ & $\sqrt{ }$ & - \\
\hline $\begin{array}{l}\text { National/regional press } \\
\text { council }\end{array}$ & $\sqrt{ }$ & $\sqrt{ }$ & $\sqrt{ }$ & $\sqrt{ }$ & $\sqrt{ }$ \\
\hline Continuous education & - & - & - & - & - \\
\hline Movie or TV series & - & - & - & - & - \\
\hline
\end{tabular}

Source: USP Journalism survey, 2005.

54 PACIFIC JOURNALISM REVIEW 11 (2) 2005 
in Fiji - particularly its impact on the community and its values. Made up of public members and civil society volunteers, the FMW is involved in organising media advocacy workshops to provide understanding and practical skills on media advocacy and media monitoring within a human rights framework. Schools and media literacy are its special focus.

The CCF and the USP journalism programme jointly organised a Freedom of Information Law for Fiji seminar in Suva in September 2004 featuring journalists, journalism educators, parliamentarians, NGOs, public officials and the Fiji Law Society. The workshop looked at strategies for campaigning for a FOI law in Fiji (A Freedom of Information Law for Fiji, 2004).

The FIAS publishes Fijian Studies: A Journal of Contemporary Fiji, which apart from socio-economic issues also looks at the media. Another media analytical journal is Pacific Journalism Review, which published for nine years at the University of Papua New Guinea and USP. Although it is now based at New Zealand's Auckland University of Technology, it has not lost its Pacific Islands focus.

Two other media journals based in Papua New Guinea - Tokwin (UPNG) and Contemporary PNG Studies (DWU)_-provide important independent analysis and commentary on the PNG media, which after Fiji is the largest in the region. Yet another publication is David Robie's journalism textbook, Mekim Nius (2004), which looks at the inter-connectedness between media education and training and wages and working conditions - and their impact on media standards, including ethics.

Robie argues that better working conditions and higher levels of training and education as opposed to short-course training are critical for empowering a new generation of journalists to effectively tackle the challenges in a globalised world:

It is vital that journalists have a good analysis of the role of the media and its relationship with good governance, freedom of speech, human rights and executive power. Only a genuine understanding of what is at stake can give journalists the will and the wisdom not to bow to the considerable pressures on South Pacific media freedom by governments, businesses and corporate power, and by non-governmental organisation. (Robie, 2004, p. 239)

Robie's 2001 survey also found that while journalists in both Fiji and PNG 
regarded their professional role as a watchdog on democracy, 53 percent of Fiji journalists and 60 percent of PNG journalists were considering leaving the profession after five years for more lucrative careers (2004, p. 243). Research publications like Robie's bring critical media issues into the public arena for debate and force media owners to act. Several media companies in Fiji now have in-house training programmes.

Yet another external $\mathrm{M}^{*} \mathrm{~A} * \mathrm{~S}$ active in Fiji is femLINKPACIFIC: Media Initiatives for Women, whose Suitcase Radio broadcasts in rural areas target women. It operates in partnership with the Foundation for the Rural Integrated Enterprises and Development (FRIENDS) and the Partners in Community Development Fiji (PCDF) to give media access to marginalised rural women. The broadcasts have been facilitated by the Foundations of the People of the South Pacific International (FSPI) as part of a regional programme with the Asia Development Bank (ADB), which aims at promoting good governance, accountability and raising awareness on national budget. femLINKPACIFIC coordinator, Sharon Bhagwan-Rolls outlines the aims of the organisation:

As femLINKPACIFIC is a member of the World Association of Community Radio Broadcasters (AMARC), we are also trying to promote the use of community radio as a tool for information and communication within local communities ... (S. Bhagwan-Rolls, personal communication, 2005)

A very visible and active form of internal $\mathrm{M}^{*} \mathrm{~A} * \mathrm{~S}$ in practice in regional newspapers is the letters to the editor column. Of the three dailies in Fiji, The Fiji Times letters column is the most robust, carrying up to 15 letters each day. The paper has not shied from running letters critical of its coverage and of its journalists. The Fiji Sun devotes three-quarters of page six from Monday to Saturday to an average six to eight letters daily while the Daily Post, which has the lowest circulation of the three, runs between three to four letters daily.

In isolation, the independence and effectiveness of the correction boxes and in-house code of ethics are questionable. Whether the letters run by the papers are a fair representation is also an ongoing issue. However, these gaps can be effectively filled by the other forms of $\mathrm{M}^{*} \mathrm{~A} * \mathrm{~S}$ such as independent media councils hearing complaints and publicising breaches. That other coun- 
tries in the region have embarked upon the path of establishing media councils is then surely a positive sign.

However, commentators such as Robie believe the media can and should do more. It could adopt another form of $\mathrm{M}^{*} \mathrm{~A}^{*} \mathrm{~S}$ missing in Fiji and elsewhere in the Pacific - 'mediawatch' style programmes on radio, TV and print. Former USP journalism lecturer Ingrid Leary used to write a weekly Mediawatch column in the Daily Post (1998-9) where she examined current ethical issues in the Fiji media but there has been nothing like it since. Robie believes that if there were more media watch-type critiques, the media would be less defensive when criticised and more open to debate.

There is an attitude that the 'media isn't news'. On the contrary, it definitely is news. If there was more coverage of media issues and trends, the general public would be better informed and more discerning - and more media savvy. (D. Robie, personal communication, 2005)

Bertrand concurs. In calling for a 'media reporter', he says the media tends to keep quiet about its own business when the public actually needs to be kept informed. A media reporter must specialise in that field so as to cover its news well and investigate the media uncompromisingly (Bertrand, 2000, p. 117).

\section{The Pacific Islands context}

It has become fashionable for Pacific Island governments to attack media standards, or the effectiveness of existing self-regulating mechanisms, then suggest 'better alternatives', such as legislation criminalising and punishing breaches through fines or jail terms. In introducing the draft Media Council of Fiji Bill, Prime Minister Laisenaia Qarase described journalists as inept while his then information minister, Simione Kaitani, denounced the Fiji Media Council as powerless to protect the public from biased and ill-informed journalists (Singh, 2003).

In mature democracies, there is less danger of governments using debates about media standards as a pretext to bring in more stringent media laws. The situation in many Pacific Island countries, where the media has been a thorn in the side of corrupt and inefficient governments, is different.

Pacific Island governments have a history of trying to find means and ways to gag the media. While claiming to be democratic, such governments 
tend to behave rather autocratically. Robie (2003) believes the press in Tonga operates under an authoritarian system while elsewhere in the Pacific, including in countries such as Fiji that are commonly regarded as having a free press, authoritarianism remains strong.

Politicians frequently speak out on how the media ought to be 'responsible', i.e. either self-censor to the benefit of the government of the day, or propagandise on its behalf. Normal independent reporting and questioning by the media is often seen by some politicians as tantamount to subversion. Thus politicians are often tempted to impose gagging or licensing laws. (Robie, 2003, p. 5)

Taimi o' Tonga publisher Kalafi Moala believes the Tongan government has used the cover of cultural traditions, the establishment of 'responsible media' and whatever else it needs to conceal its wish not to be questioned or criticised (Moala, 2002, p. 65). The temptation to impose gags is greater now as the island media grows bigger, bolder, and becomes more influential, reporting more aggressively as competition intensifies. While concerns have been expressed by ordinary people about professionalism, taste, decency and privacy, which they feel are being trampled in the race for ratings and circulation, opportunistic governments have jumped on the bandwagon and their calls for media control and censorship are heard the loudest.

Inevitably, such governments attack media standards, claim that current self-regulating devices that are in place are not working and call for more controls. The behaviour of the Fiji government in its introduction of the $\mathrm{Me}$ dia Council of Fiji Bill is a case in point. But the focus on media councils is unwarranted and one-sided when there are several other supplementary and complementary $\mathrm{M}^{*} \mathrm{~A} * \mathrm{~S}$ at work. These are conveniently ignored by governments pushing for more stringent controls.

\section{Conclusion}

Media councils in Oceania are scorned and often dismissed as lackeys of the media companies that finance them and form part of their structure. But despite all their imperfections, media councils are an effective way, particularly in Pacific Island countries, to thwart governments' desire to control the media. While they are not flawless, self-regulatory media councils provide the best opportunity for the island media to carry out its watchdog function with- 
out undue influence from those who need to be watched the most-governments.

While criticism of self-regulatory media councils have led to their improvement and development over the years, and are essential to keep them accountable and on their toes, it has to be tempered in the Pacific media context with the knowledge that autocratically-orientated governments are eager to turn such debates against the media to bring in controls. These governments turn a blind eye to the fact that press and media councils are but one form of $M^{*} A^{*} S$ - that there are several different $M^{*} A * S$ that are in motion and that supplement and compliment the media councils.

That self-regulation by the media is not perfect is a fact that has to be accepted, just as it should be understood that it is unlikely that any system will ever be perfect. But the search for perfection should not to be abandoned. It should be ongoing, just as it has been. It opens media accountability systems to criticism and scrutiny. The system has been responsive to criticism, reforming and restructuring to correct weaknesses. This self-examination and self-evaluation, as history has shown, may have not led to perfection, but has led to continuous improvements and has given rise to many forms of $\mathrm{M}^{*} \mathrm{~A} * \mathrm{~S}$. It is in their own interest that the media in Oceania recognise and adopt other $\mathrm{M}^{*} \mathrm{~A} * \mathrm{~S}$, such as mediawatch-type programmes and columns. It has to realise that if such $\mathrm{M}^{*} \mathrm{~A}^{*} \mathrm{~S}$ are functioning properly, it makes it harder for governments to intervene and bring in regulation.

\section{References}

About the Media Council Inc. (n.d.) (Retrieved 12 September 2005) www.matangitonga.to/home/ads/media-council/ngo.shtml

Bertrand, C.-J. (2000). Media ethics and accountability systems. New Brunswick (US) and London (UK): Transaction Publishers.

Complaints procedure. (2003). Fiji Media Council. (Retrieved 15 September 2005). www.fijimediacouncil.com/complain-procedures.htm

Confessions of a Prime Minister. (1994, April). The Review, p. 11.

Cook Islands PM announces creation of media council. (2004, April 13). RANews Online/Pacific Media Watch. (Retrieved 15 August 2005). www.presscouncils.org/ aipce_index.php

Cautious welcome for 'media council' plan. (2004, March 13). Pacific Media Watch. (Retrieved 15 August 2005). www.pmw.c2o.org/2004/cookis4344.html

Elsaka, N. (2001). The politics of voluntary restraint: The development of self-regulatory codes by the British and New Zealand media. Australian Journalism Re- 
MEDIA ETHICS AND ACCOUNTABILITY

view, 23(2):160.

A Freedom of information law for Fiji. (2004). A public workshop hosted by the Citizens Constitutional Forum Ltd and the USP Journalism Programme, Suva. September .

Keeble, R. (2005). Journalism ethics: Towards an Orwellian critique? In Allan, S. (Ed.)., Journalism: Critical issues (p.55.). Berkshire: England.

Media offenders to scream first, says George. (March, 2004). Cook Islands Government website. (Retrieved 15 August 2005): www.cook-islands.gov.ck/ view_release.php?release id=522

Moala, $\bar{K}$. (2004). Media ownership in Oceania: Tonga. Pacific Journalism Review, September, 10(2): 65.

Morgan., K. and Thomas, J. (1996). Future Media Legislation and Regulation for the Republic of the Fiji Islands. Consultancy report prepared for the Government of the Fiji Islands.

Politicians 'want media on leash'. (2004, March 12). Pacific Media Watch. (Retrieved 12 August 2005): www.pmw.c2o.org/2004/cookis4343.html

Press Councils Directory. (Retrieved 13 September 2005): www.presscouncils.org/ $1 \mathrm{i}$ b r a r y / M A S \% 20 ( 80 ) \% $20 \mathrm{~J}$ a n u a r y \% 202003. doc?PHPSESSID=e85967de81fd8aa495d592bfc7674820

Robie, D. (2004). Mekim News: South Pacific media, politics and education. Suva: University of the South Pacific.

Robie, D. (2003). Pacific media councils and cultural values: Safety valve or entrenched hegemony? Pacific Journalism Review, September, 9(1):103-122.

Singh, S. ( 2003, June) Encouragement through coercion. Wansolwara, p. 12.

Solomon Islands: Policies. (2005). Media Council of Papua New Guinea and Media Association of the Solomon Islands website. (Retrieved 20 August 2005): www.pngsimediacouncil.org/page.php?id=210

Shailendra Singh is coordinator of the University of the South Pacific journalism programme and a former editor of The Review news magazine. The author wishes to thank final-year International Journalism students at USP for their assistance while engaged on a media accountability systems $\left(M^{*} A * S\right)$ research project in March 2005.

singh_sh@usp.ac.fj 
Copyright of Pacific Journalism Review is the property of Auckland University of Technology and its content may not be copied or emailed to multiple sites or posted to a listserv without the copyright holder's express written permission. However, users may print, download, or email articles for individual use.

http://Mww.aut.ac.nz/depts/commstud/journ/pjrsubs.shtml 